\title{
Diel vertical migration of Cladocera in a compartment of a tropical reservoir
}

\author{
Migração vertical diurna de Cladocera em um compartimento de um \\ reservatório tropical
}

Erika dos Santos Silva ${ }^{1 *}$, Odete Rocha ${ }^{1}$ and Maria José dos Santos-Wisniewski ${ }^{2}$

\begin{abstract}
${ }^{1}$ Departamento de Ecologia e Biologia Evolutiva, Universidade Federal de São Carlos - UFSCar, Rodovia Washington Luís, Km 235, CEP 13565-905, São Carlos, SP, Brasil

${ }^{2}$ Laboratório de Limnologia, Universidade Federal de Alfenas - UNIFAL, Rua Gabriel Monteiro da Silva, 700, CEP 37130-001, Alfenas, MG, Brasil

*e-mail: erika_2990@hotmail.com
\end{abstract}

Cite as: Silva, E.S., Rocha, O. and Santos-Wisniewski, M.J. Diel vertical migration of Cladocera in a compartment of a tropical reservoir. Acta Limnologica Brasiliensia, 2018, vol. 30, e304.

Abstract: Aim: This study seeks to analyze the vertical migration pattern of Cladocera species as related with the physical and chemical parameters of the water. Methods: Samplings were carried out at 3-h intervals for $24 \mathrm{~h}$ in January 15 on the Sapucaí River compartment of Furnas reservoir, Minas Gerais State, Brazil. These samples were taken at five depths, from the surface to the near-bottom layer $(0,2,4,6,8$, and $9 \mathrm{~m})$ totalizing 54 samplings for each limnological variable (temperature, $\mathrm{pH}$, dissolved oxygen, electrical conductivity, chlorophyll- $a$ content, Index of Trophic State, water transparency and Cladocera populations abundance). The samplings were performed at the limnetic region at a point with total depth of 9 meters. Results: Water column thermal and chemical stratifications and thermocline occurrences were registered in the middle of the day. Among the 14 Cladocera species, only Ceriodaphnia cornuta and C. silvestrii displayed a significant migration pattern, which was mainly related to chlorophyll- $a$ and dissolved oxygen concentrations. Diaphanosoma birgei and D. spinulosum are found at high densities near the surface and low ones in depth. The migration of Diaphanosoma was directly related to the concentration of chlorophyll $a$ and $\mathrm{pH}$, thus acting as a limiting factor. Feeding at high temperatures in the surface layer and assimilating at lower ones in depth, usually confer metabolic advantages to the vertically migratory species. Conclusions: In this study, a well-defined pattern of vertical migration was found for two Cladocera species and its possible causes were hypothesized. To the species with less locomotory capacity, thermal and chemical stratifications can act as barriers to migration and distribution through the water column. This pattern may probably be found for zooplankton species in other compartments of Furnas reservoir, with similar physical and chemical properties.

Keywords: nictemeral variation; zooplankton; Furnas; stratification.

Resumo: Objetivo: Este estudo procura analisar o padrão de migração vertical das espécies de Cladocera e relacionar com os parâmetros físicos e químicos da água. Métodos: As amostragens foram realizadas em intervalos de três horas por um período de 24 h no dia 15 de janeiro de 2014 no compartimento do rio Sapucaí, reservatório de Furnas, Minas Gerais, Brasil. Estas amostras foram coletadas em cinco profundidades, da superfície ao fundo $(0,2,4,6,8$ e $9 \mathrm{~m})$, totalizando 54 amostragens para cada variável limnológica (temperatura, $\mathrm{pH}$, oxigênio dissolvido, condutividade elétrica, teor de clorofila- $a$, índice de estado trófico, transparência da água e Cladocera). As amostragens foram realizadas na regiáo limnética em um ponto com profundidade total de 9 metros. Resultados: As 
estratificaçóes térmicas e químicas da coluna de água e as ocorrências da termoclina foram registradas no meio do dia. Entre as 14 espécies de Cladocera, apenas Ceriodaphnia cornuta e C. silvestrii apresentaram um padrão de migraçáo significativo, principalmente relacionado às concentraçóes de clorofila $a \mathrm{e}$ oxigênio dissolvido. Diaphanosoma birgei e D. spinulosum foram encontrados em altas densidades na superfície e meio da coluna d'água. A migração de Diaphanosoma spp foi diretamente relacionada à concentração de clorofila $a$ e $\mathrm{pH}$, que atuaram como um fator limitante. A alimentação em altas temperaturas na camada superficial e a assimilação nas camadas mais profundas podem conferir vantagens metabólicas às espécies migratórias verticais. Conclusóes: Neste estudo, um padrão bem definido de migraçáo vertical foi encontrado para duas espécies de Cladocera e suas possíveis causas foram hipotetizadas. Para espécies com menor capacidade locomotora, as estratificaçóes térmicas e químicas da água podem ter atuado como uma barreira à migração e distribuição através da coluna d'água. Este padrão pode provavelmente ser encontrado para espécies zooplanctônicas em outros compartimentos do reservatório de Furnas, com propriedades físicas e químicas semelhantes.

Palavras-chave: variação nictemeral; zooplâncton; Furnas; estratificação.

\section{Introduction}

Diel vertical migration (DVM) is typical of both marine and continental zooplankton species, which was originally described by Cuvier (1817). Zooplankton species presents two basic types of DVM, a downward movement of individuals in the morning and an upward motion in the evening, which characterizes the "normal" pattern of migration (Ohman et al., 1983; Bayly, 1986; Lampert, 1989). Moreover, there is a reverse migration movement, caused mostly by the presence of invertebrate predators. This reverse migration consists of an ascent move to the surface layer during the day and descent to a maximum depth at night. There is also a twilight migration, marked by two peaks in density values, one at sunrise, and another at sunset (Hutchinson, 1967; Minto et al., 2010) values.

Many authors have suggested that the vertical migration has some adaptive in the community (Hardy, 1936; Lampert, 1989; Hays, 2003). For example, the alternation between feeding at higher and resting at lower temperatures provides metabolic advantages to the organisms. Besides the temperature, several other factors may control the vertical distribution of zooplankton community such as dissolved oxygen concentration, light intensity and planktivorous predators (Lampert, 1989; Dodson, 1990; Wissel \& Ramacharan, 2003; Picapedra et al., 2015) and food availability (Flik \& Ringelberg, 1993; Freitas et al., 2012). Climatic factors like rainfall and temperature can alter the dynamics of tropical reservoirs, leading to short-term changes in the structure of the community present in these environments. Studies on the dynamics of zooplankton from tropical reservoirs provide understanding for many environmental processes along its vertical gradient, as well as to possible ecological interactions among the species (Domis et al., 2013).

Several studies on the migration of zooplankton were already carried out in Brazil such as that from Nogueira \& Panarelli (1997) and Santos et al. (2015) which evaluated the vertical migration and zooplankton variation in the Jurumirim and Guarapiranga reservoirs, Upper Tietê River Basin (São Paulo State) in two diurnal cycles, respectively. In Minas Gerais State, some researchers investigated the nictemeral variations of zooplankton in water bodies in the Rio Doce Valley (Matsumura-Tundisi et al., 1984, 1997; Matsumura-Tundisi, 1997; Maia-Barbosa et al., 2003). Bezerra-Neto et al. (2009) verified predation influence in the nictemeral variation of zooplanktonic organisms in Carioca lake and Nado reservoir. Bezerra-Neto \& Pinto-Coelho (2007) related the vertical diurnal migration of the Copepoda Thermocyclops inversus in the Nado reservoir with dissolved oxygen concentration and the presence of Chaoborus larvae. In these two studies, the presence of this predatory species influenced the distribution of zooplankton organisms and caused an inverse migratory behavior of Thermocyclops inversus as a escape strategy to predation.

In these freshwater ecosystems, thermal stratification and destratification were important environmental factors influencing the system vertical organization and the seasonal reorganization of biological communities. The thermal variations occurring in tropical reservoirs whether during the diurnal (nictemeral) or seasonal cycle, together with vertical or horizontal gradients, also have physiological importance to the organisms (Kingsolver, 2009; Sartori et al., 2009; Domis et al., 2013). According to Thackeray et al. (2006), stratification conditions and water column mixing 
can directly affect the pattern of vertical distribution of the zooplankton.

Therefore, short-term studies such as nictemeral variations (over a 24 hour period) may be an important tool for understanding important patterns on the distribution of local zooplankton populations during the diurnal cycle, including their vertical migration and the factors responsible for the temporary changes observed in the structure of the community (Cody, 1996; Zanata \& Espindola, 2002; Sartori et al., 2009). Thus, the present study aimed to assess the vertical migration of Cladocera populations in a tropical reservoir compartment as a function of water column physical and chemical properties, to identify which of these factors were contributing most to the species migration.

\section{Material and Methods}

\subsection{Study area}

Furnas Reservoir (FR) is located in Minas Gerais state, Brazil, and consists of two large compartments, including Grande and Sapucaí Rivers (FURNAS, 2015). It has an area of $1,440 \mathrm{~km}^{2}$, a volume of 22.95 billion $\mathrm{m}^{3}$ water (Landa et al., 2002), high water residence time (mean around 160 days), and dendritic morphology, providing gradients along the horizontal and vertical directions, resulting in different trophic gradients (Sá-Junior, 1994; Santos et al., 2010; Melo et al., 2017).

According to Santos et al. (2010), the surroundings of the Sapucaí River are densely populated, what has caused a progressive degradation, mainly due to the release of industrial, agricultural, and sanitary residuary wastes into the watercourses. The present study was carried in a fixed sampling station $\left(21^{\circ} 22^{\prime} 16^{\prime \prime} \mathrm{S}\right.$ and $\left.46^{\circ} 00^{\prime} 06^{\prime \prime} \mathrm{W}\right)$ on the Sapucaí River compartment of Furnas reservoir, Minas Gerais State, Brazil. These segments of the reservoir receive an effluent discharge point from the sewage treatment plant of the city of Alfenas. The samplings were performed at one point of the limnetic region with total depth of 9 meters (Figure 1).

\subsection{Sampling and identification}

Samplings were collected in the limnetic region of reservoir at nine water column depths: $0,2,4,6,8$ and 9 meters. Water and cladocerans samplings were carried out at 3-h intervals along $24 \mathrm{~h}$ in January 2014 (days 15 -16), first sampling starting at 10:00 am. For each depth, samplings were performed for both, the study of the zooplankton community and of physical and chemical conditions (dissolved oxygen, chlorophyll $a, \mathrm{pH}$, conductivity,
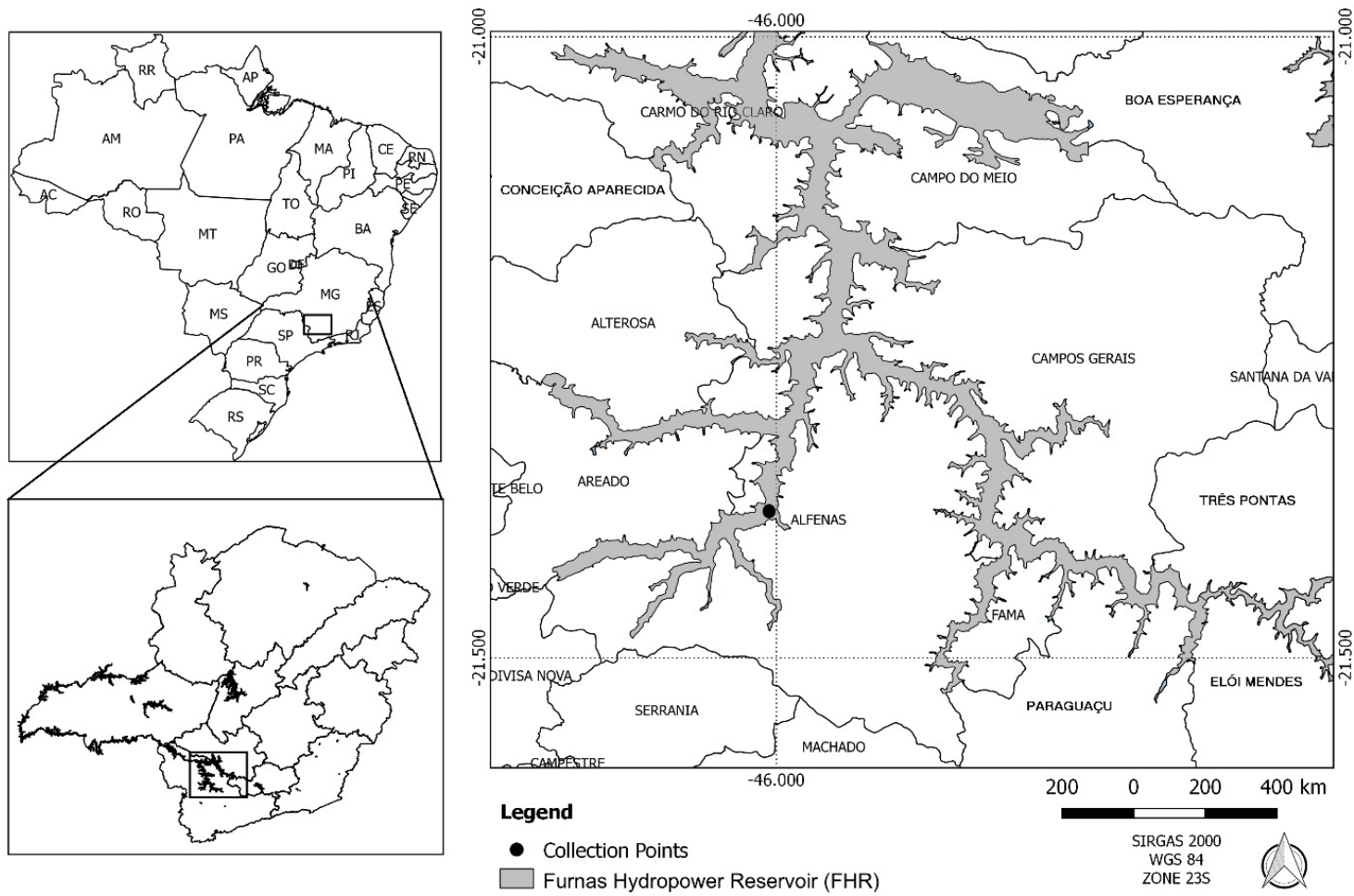

Figure 1. Localization of sampling station in Sapucaí River compartment of Furnas Reservoir, Minas Gerais State, Brazil. 
temperature and nutrients) totalizing 54 samplings for each variable and for the zooplankton.

Several studies of nictemeral variation have been carried out in Brazil and most part of these studies were carried out by sampling every three or four hours, and at various depths in the water column (Previattelli et al., 2005; Silva et al., 2011; Matsumura-Tundisi et al., 1997; Matsumura-Tundisi, 1997; Mitamura \& Hino, 1997; Maia-Barbosa et al., 2003). These papers referenced our study.

Water temperature, dissolved oxygen concentration, electrical conductivity and $\mathrm{pH}$ were measured by an Horiba U-50 multisensor, at each depth of the water column, and water transparency was determined from Secchi disk readings. The chlorophyll- $a$ concentration was determined using the $90 \%$ acetone extraction method, as described by Golterman et al. (1978). Nutrient concentrations were estimated following the methods proposed by the American Public Health Association, American Water Works Association and Water Pollution Control Federation (APHA, 2012). The Carlson index, adapted by Toledo et al. (1983) was used for trophic status classification of environment. Samplings for analyses of vertical distribution and nictemeral migration of Cladocera populations were performed using 5 liters Van Dorn bottle. Samples were filtered through a plankton net (68 $\mu \mathrm{m}$ mesh), fixed with $4 \%$ formaldehyde solution saturated with sugar.

The organisms were counted using a square patterned acrylic plate (20x50 fields) under a Zeiss stereomicroscope (model Stemi 2000), with up to 40 times magnification. Subsamples were counted until reachung 100 individuals of each species. For rare or low density organisms, the entire sample was considered. The identification was carried out using specialized literature (Paggi, 1972; Smirnov, 1996; Elmoor-Loureiro, 1997; Hudec, 2000; Kotov et al., 2009; Van Damme et al., 2011). During sampling, the presence of Chaoborus sp. (Insecta, Diptera) was also registered. Although not fully planktonic, the counting of this species was performed to relate its presence to Cladocera migration.

\subsection{Data analysis}

The frequency of occurrence of Cladocera species was calculated according to Dajoz (1983), being classified as constant when present in more than $50 \%$ samples, accessory in 25 to $50 \%$, and accidental in less than $25 \%$. Only the constant species and with high abundance were used for vertical migration pattern verifications. The analysis was carried out using the application OriginPro 8.0 (Microcal Inc.). Principal component analysis (PCA) was used to evaluate the relationship between samplings and the physical and chemical factors of water columns for daytime, using Canoco 4.5 (Ter-Braak \& Šmilauer, 2002). A Pearson correlation tests were performed among selected environmental variables, followed by an analysis of variance (ANOVA). The multiple regression analysis $(\mathrm{p}<0.05)$, available in version software Statistica $^{\text {TM }} 13.0$ (StatSoft, 2005) was conducted to assess the effects of physical and chemical parameters of water (temperature, dissolved oxygen concentration, $\mathrm{pH}$, electrical conductivity, chlorophyll-a content and water transparency) on Chaoborus sp. larvae occurrence and on the vertical distribution pattern of the zooplankton species. Densities of each migratory species were correlated to the environmental variables, and the effect of each variable was considered significantly influencing their migration for values of $\mathrm{p}<0.05$.

\section{Results}

The water column was stratified thermally and chemically during the study period (Figure 2). During the first hours of study $(10 \mathrm{am}, 01 \mathrm{pm}$ and $04 \mathrm{pm}$ ), thermoclines started from 6 to 7 meters in depth. A micro-stratification was also observed at the epilimnion through this period. Throughout the day, a high difference in temperature between the surface and bottom was observed, reaching $6{ }^{\circ} \mathrm{C}$. This micro-stratification was less evident in the epilimnion in the samplings at $7 \mathrm{pm}, 10 \mathrm{pm}$ and $4 \mathrm{am}$.

The dissolved oxygen concentrations showed the same stratification pattern, with higher concentrations at the surface and lower ones at the bottom (Figure 2). A direct positive correlation between dissolved oxygen concentration and water temperature was observed $(\mathrm{r}=0.8043)$. The lowest concentration $\left(0.75 \mathrm{mg} \mathrm{L}^{-1}\right)$ was observed at $07 \mathrm{am}$, in a depth of 9 meters, approaching anoxia.

No significant variations in electrical conductivity and $\mathrm{pH}$ were found for any of the samples (ANOVA with $\mathrm{p}=0.28$ and $\mathrm{F}=1.23$ ). The mean water conductivity was $54 \pm 11 \mu \mathrm{S} \mathrm{cm}^{-1}$, while the mean $\mathrm{pH}$ was $7.8 \pm 1.1$.

Fourteen species of Cladocera were recorded. The most constant and with highest abundances species were the ones selected for the vertical migration analysis, as follows: Bosmina cf. longirostris 
De Melo \& Hebert, 1994, Ceriodaphnia cornuta Sars, 1885, C. silvestrii Daday, 1902, Chydorus pubescens Sars, 1901, Diaphanosoma birgei Korinek, 1981 and D. spinulosum Herbst, 1975 (Table 1). For Ceriodaphnia cornuta the sum of the abundances of the three morphotypes: C. cornuta cornuta, C. cornuta intermedia and C. cornuta rigaudi was considered, although $C$. cornuta cornuta was the one with highest contribution for the analysis due to its highest relative density.

A nocturnal migration pattern was observed throughout the nictemeral cycle for Ceriodaphnia silvestrii and C. cornuta species (Figure 3). The highest densities were recorded
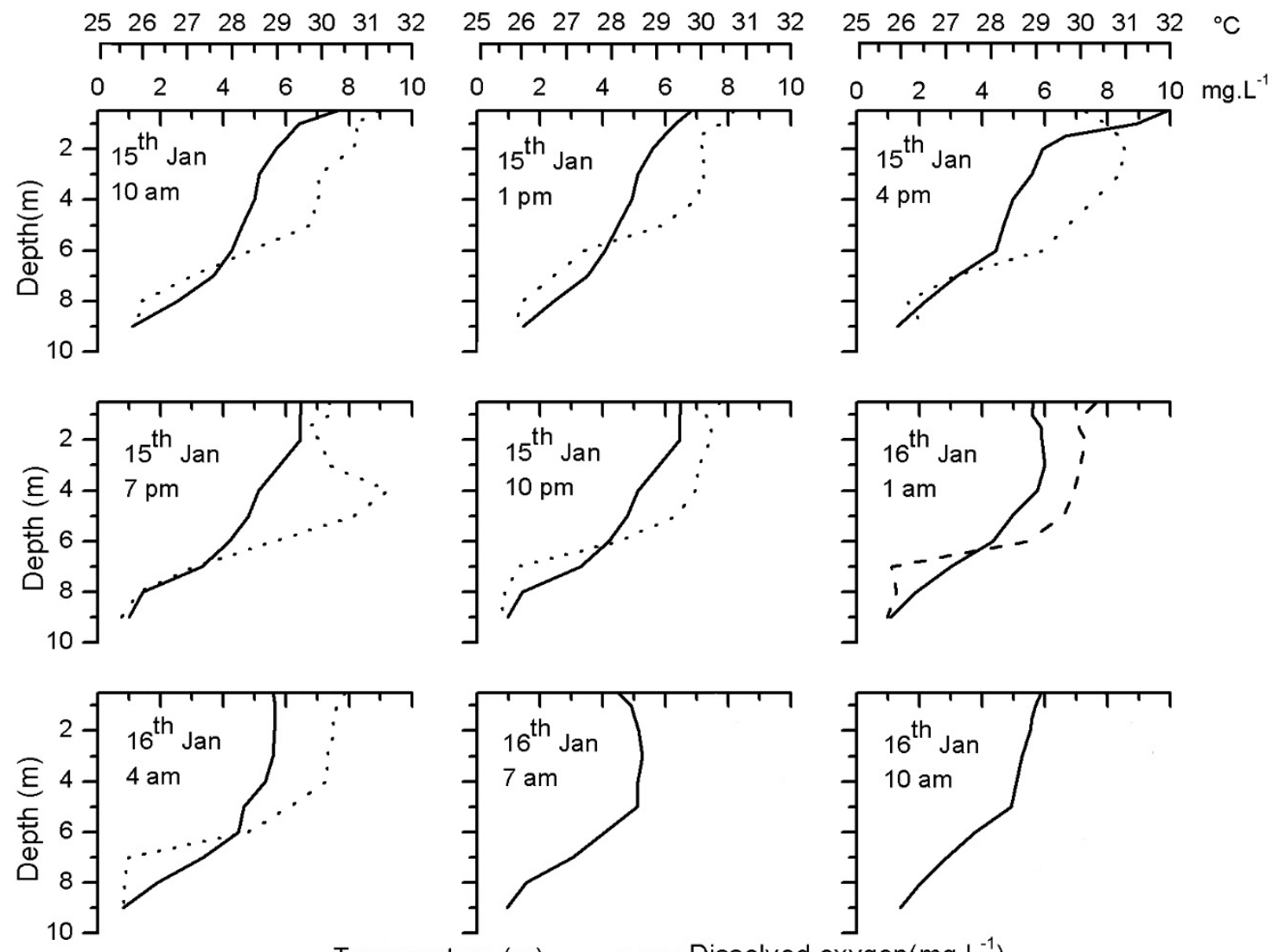

- Temperature $(\mathrm{m})$

- - - Dissolved oxygen(mg. $\left.\mathrm{L}^{-1}\right)$

Figure 2. Water temperature $\left({ }^{\circ} \mathrm{C}\right)$ and dissolved oxygen concentration $\left(\mathrm{mg} \mathrm{L}^{-1}\right)$ profiles, for every depth and time sampling, at a study station in Furnas Reservoir, from 10 am of January 15 to 10 am of January 16, 2014.

Table 1. Dajoz Constance Index (DCI) of Cladocera species recorded at a sampling station (January 2014) in Furnas reservoir, Minas Gerais State, Brazil.

\begin{tabular}{lcc}
\hline \multicolumn{1}{c}{ Cladocera species } & $\%$ & DCl \\
\hline Anthalona verrucosa (Sars, 1901) & 2 & Accidental \\
Bosmina cf. longirostris De Melo \& Hebert, 1994 & 94 & Constant \\
Bosmina cf. hagmanni Stingelin, 1904 & 44 & Accessorial \\
Bosminopsis deitersi Richard, 1895 & 2 & Accidental \\
Ceriodaphnia cornuta Sars, 1885 & 98 & Constant \\
Ceriodaphnia silvestrii Daday, 1902 & 98 & Constant \\
Chydorus eurynotus Sars, 1901 & 4 & Accidental \\
Chydorus pubescens Sars, 1901 & 87 & Constant \\
Daphnia gessneri Herbst, 1967 & 6 & Accidental \\
Diaphanosoma birgei Korinek, 1981 & 98 & Constant \\
Diaphanosoma brevireme Daday, 1905 & 7 & Accidental \\
Diaphanosoma spinulosum Herbst, 1975 & 100 & Constant \\
Kurzia polyspina Hudec, 2000 & 2 & Accidental \\
Moina minuta Hansen, 1899 & 33 & Accessorial \\
\hline
\end{tabular}


during the daytime at water column deepest layers. However, these species migrated to the surface in the evening and came back to higher depths in early morning. Bosmina cf. longirostris, Chydorus pubescens and Diaphanosoma spnulosum displayed short movements during the studied period. These species migrated short distances, from the surface to the middle of the water column. Bosmina cf. longirostris showed the highest population density on the surface most of the time, except at $10 \mathrm{pm}$ when there was a short movement to $2 \mathrm{~m}$ depth, displaying the highest density in this region (Figure 4). Chydorus pubescens presented the highest densities in the middle of the water column at $01 \mathrm{pm}$ and $04 \mathrm{pm}$, but at $07 \mathrm{pm}$ and $01 \mathrm{am}$, there was an ascendant movement to the surface (Figure 4). No well-defined migration pattern was found for Diaphanosoma birgei and D. spinulosum, which maintained highest densities on the surface. Density increases were verified at $5 \mathrm{~m}$ depth during night time for $D$. birgei and in the middle of the water column at 01 am for D. spinulosum (Figure 5).
A vertical migration of individuals belonging to this genus Chaoborus sp. was observed, showing highest densities on the surface in the evening, from $07 \mathrm{pm}$ to 01 am (Figure 6).

For much of the studied period, the highest concentrations of chlorophyll- $a$ were found near the surface, but in the evening, from $07 \mathrm{pm}$ to $01 \mathrm{am}$, it decreased on the surface and increased in the middle of the water column (Figure 6). In the early morning, the previous concentration was restored, with the lowest value $\left(0.39 \mu \mathrm{g} \mathrm{L} \mathrm{L}^{-1}\right)$ at $8 \mathrm{~m}$ depth at $07 \mathrm{am}$, and the highest $\left(7.75 \mu \mathrm{g} \mathrm{L}^{-1}\right)$ on the surface at $10 \mathrm{am}$.

The Sapucaí River compartment was classified as mesotrophic. The water transparency varied from 1 to $1.3 \mathrm{~m}$ depth throughout the daytime and the depth of the euphotic zone varied from 2.7 to $3.51 \mathrm{~m}$.

The PCA showed strong relationships, as evidenced by the high explicability attained by the first two factor axes, which together explained $96 \%$ of the total variance (Figure 7 ). The samples

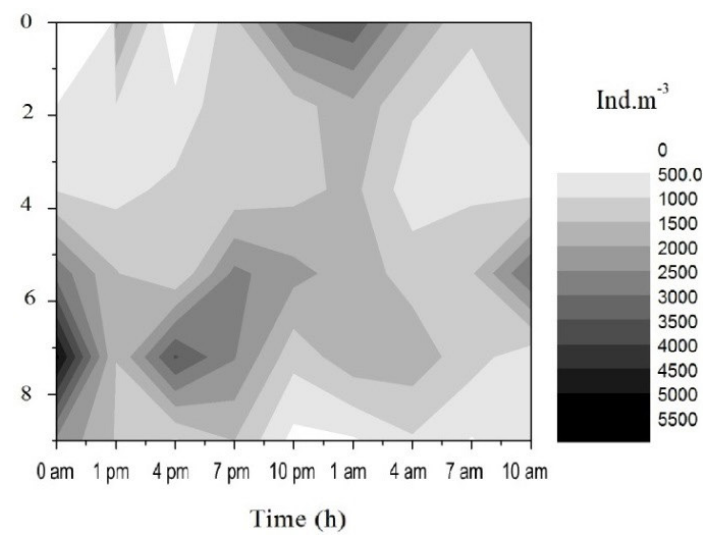

Figure 3. Vertical variation in population density of Ceriodaphnia silvestrii and Ceriodaphnia cornuta (ind.m ${ }^{-3}$ ) during a single nictemeral cycle, at a study station in Furnas Reservoir, from 10 am January 15, to 10 am of January 16, 2014.
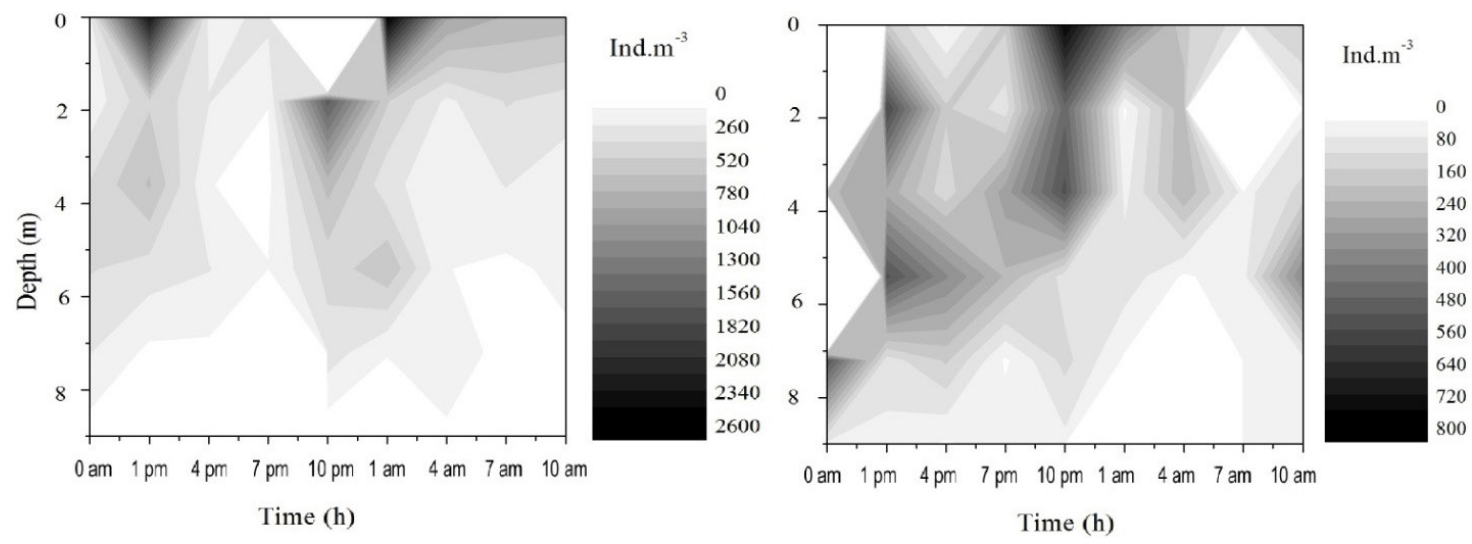

Figure 4. Vertical variation in population density of Bosmina cf. longirostris and Chydorus pubescens (ind. $\mathrm{m}^{-3}$ ) during a single nictemeral cycle, at a study station in Furnas Reservoir, from 10 am of January 15 to 10 am of January 16, 2014. 

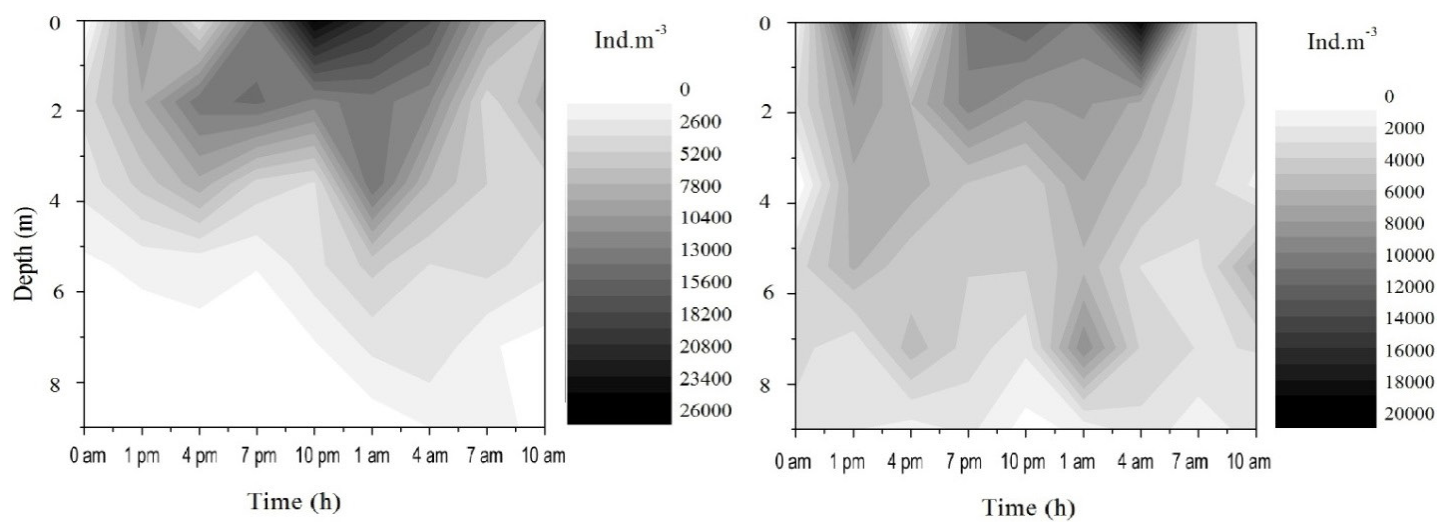

Figure 5. Vertical variation in population density of Diaphanosoma birgei and D. spnulosum (ind. $\mathrm{m}^{-3}$ ) during a single nictemeral cycle, at a study station in FR, from 10 am of January 15 to 10 am of January 16, 2014.
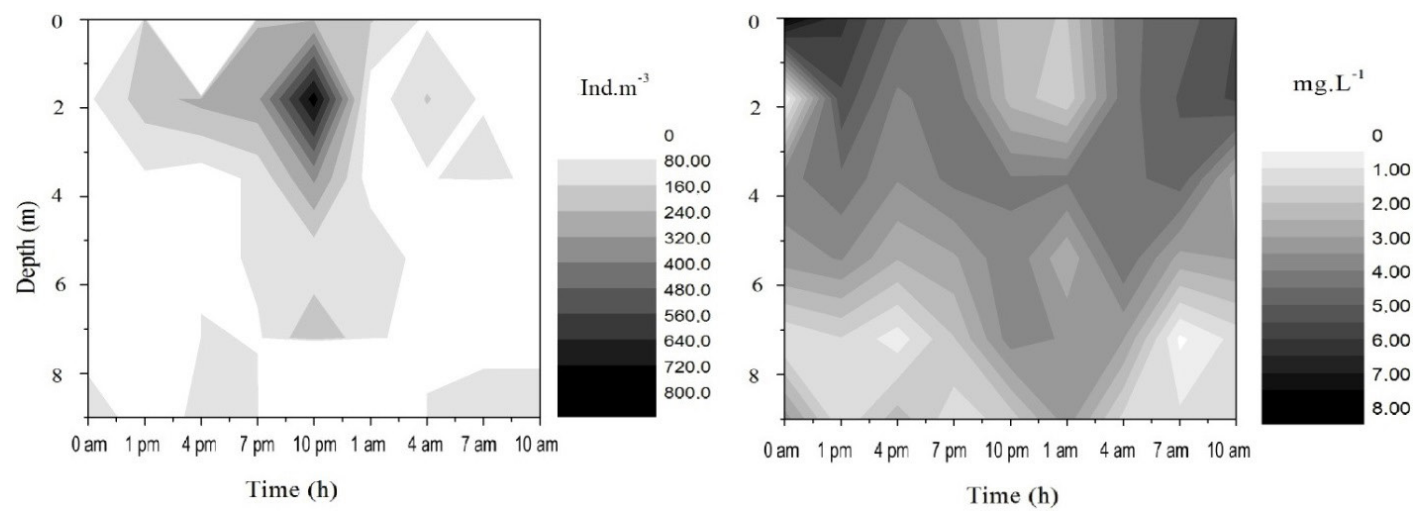

Figure 6. Vertical variation in population density of Chaoborus sp (ind. $\mathrm{m}^{-3}$ ) and Chlorophyll a concentration ( $\left.\mathrm{mg} \mathrm{L}^{-1}\right)$ during a single nictemeral cycle, at a study station in Furnas Reservoir, from 10 am of January 15 to 10 am of January 16, 2014.

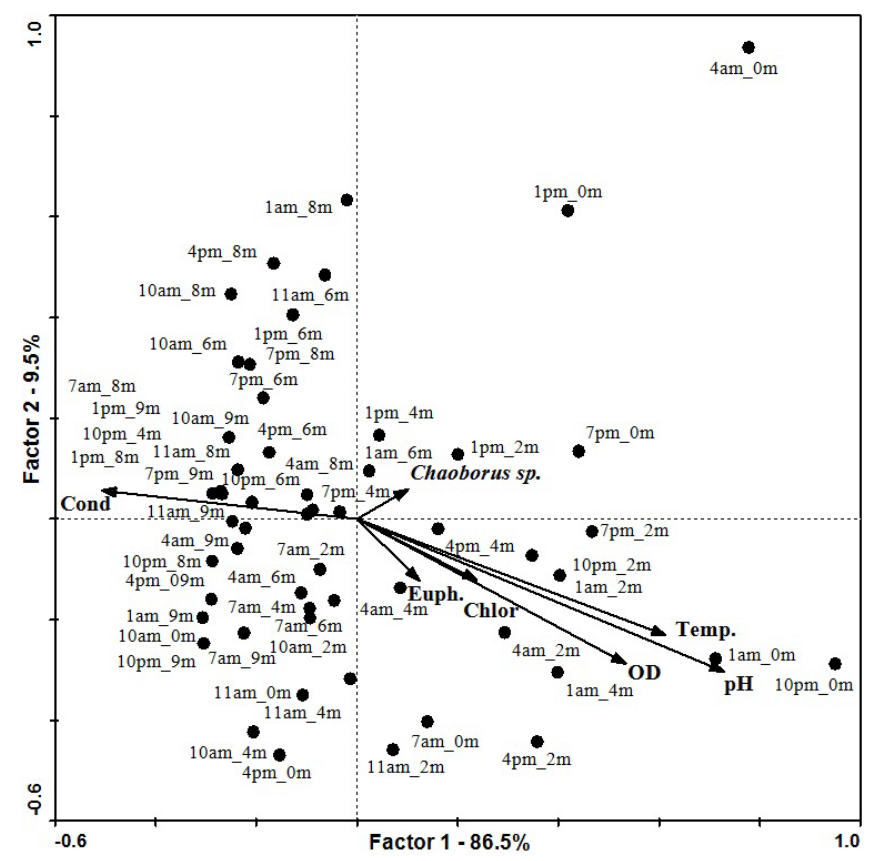

Figure 7. Principal Component Analysis (PCA) for every sample (time_depth) during a single nycthemeral cycle, at a study station in Furnas Reservoir, from 10 am of January 15 to 10 am of January 16, 2014. (Cond = electrical conductivity; Chlor $=$ Chlorophyll $a$; $\mathrm{OD}=$ dissolved oxygen concentration; Euph = euphotic zone; Temp = temperature). 
from deeper layers of the water column were positively correlated with electrical conductivity, whereas surface samples positively correlated with temperature, dissolved oxygen concentration and $\mathrm{pH}$. Notably, Chaoborus sp. larvae densities were less correlated with environmental factors.

Multiple regression analysis shows two significant correlations. The first between Diaphanosoma birgei and $\mathrm{pH}\left(\mathrm{p}<0.001, \mathrm{R}^{2}=0.8094\right)$ and chlorophyll $a\left(\mathrm{p}=0.026, \mathrm{R}^{2}=0.8094\right)$ and other between D. spinulosum and $\mathrm{pH}\left(\mathrm{p}=0.013, \mathrm{R}^{2}=0.5656\right)$. No significant correlation was observed for the migration pattern of Bosmina cf. longirostris. (Table 2). Ceriodaphnia cornuta and C. silvestrii were correlated to electric conductivity, dissolved oxygen and chlorophyll a concentration. Diaphanosoma birgei was influenced by $\mathrm{pH}$ and chlorophyll $a$ whereas $D$. spinulosum was correlated only to $\mathrm{pH}$. Bosmina cf. longirostris density apparently was not influenced (Table 2).

\section{Discussion}

Thermal and chemical stratifications are important natural events in reservoirs, creating complex gradients in the structure of these ecosystems. In reservoirs, the stratification pattern can be influenced by several factors such as climate (seasons, wind, precipitation and air temperature), water flow, morphometry, hydraulic characteristics (hydraulic stratification) and residence time (Cantin et al., 2011; Xing et al., 2014). In tropical regions, differences in temperature between the surface and the bottom of the water column produce a stable stratification over a certain period, due to changes in water density (Payne, 1986); in the present study, this difference was of $6^{\circ} \mathrm{C}$. According to the theoretical assumptions of Wetzel (2001) an environment is stratified when the temperature variation at the deepest discontinuity (thermocline) is greater than $1{ }^{\circ} \mathrm{C}$ per meter.

In the present study, although no mixing was recorded during the 24 hours study, a micro-stratification process was observed throughout the first hours. Such a result might have occurred due to the heat losses from the water surface to the atmosphere at night, and the failure of the main thermocline to be established. This event is common in tropical and shallow reservoirs (Tundisi, 1984; Santos et al., 2015). In temperate climates, the thermal stratification patterns in lakes are widely associated with the seasons. Conversely, in tropical regions where seasons are less pronounced, lake stratification tends to be associated with a sequence of short-term climatic events, such as intense solar radiation, heavy rains, cold fronts or strong winds (Hutchinson, 1967). These events promote multiple cycles of stratification and partial mixing in a short-term (Talling, 1966; Barbosa \& Padisák, 2002; Becker et al., 2009).

Dissolved oxygen concentration stratification can be inversely associated with water thermal stratification (Wetzel, 2001), as observed in this study. In another study conducted by Santos et al. (2015), in the Guarapiranga Reservoir (nearly $300 \mathrm{~km}$ away south), multiple thermoclines were observed in a single day. The stratification pattern is essential to understand the dynamics of planktonic communities in tropical lakes and reservoirs (Sarmento, 2012). These patterns may influence the migration of zooplanktonic organisms along the water column, and between different habitats, leading to heterogeneity and clustering

Table 2. Results from multiple regression analysis among the main migratory species of Cladocera and the physical and chemical parameters of water during a single nictemeral cycle, at a sampling station of Furnas reservoir, Minas Gerais State, Brazil.

\begin{tabular}{|c|c|c|c|c|c|c|}
\hline & $\begin{array}{l}\text { Bosmina cf. } \\
\text { longirostris }\end{array}$ & $\begin{array}{l}\text { Ceriodaphnia } \\
\text { cornuta }\end{array}$ & $\begin{array}{l}\text { Ceriodaphnia } \\
\text { silvestrii }\end{array}$ & $\begin{array}{c}\text { Diaphanosoma } \\
\text { birgei }\end{array}$ & $\begin{array}{l}\text { Diaphanosoma } \\
\text { spinulosum }\end{array}$ & $\begin{array}{c}\text { Chydorus } \\
\text { pubescens }\end{array}$ \\
\hline $\begin{array}{c}\text { Electric } \\
\text { conductivity }\end{array}$ & 0.92877 & $0.00115^{*}$ & $0.00438^{*}$ & 0.83030 & 0.30386 & 0.10714 \\
\hline $\begin{array}{l}\text { Dissolved } \\
\text { oxygen }\end{array}$ & 0.33957 & $0.01145^{*}$ & $0.04893^{*}$ & 0.13358 & 0.10786 & 0.26416 \\
\hline Temperature & 0.31700 & 0.65938 & 0.66164 & 0.20090 & 0.77860 & 0.83568 \\
\hline Chlorophyll a & 0.17072 & $0.02835^{*}$ & $0.02909^{*}$ & $0.02690^{*}$ & 0.32778 & 0.06557 \\
\hline Chaoborus sp. & 0.98535 & 0.96862 & 0.81108 & 0.94941 & 0.55544 & $0.01694^{*}$ \\
\hline $\mathrm{pH}$ & 0.07311 & 0.73688 & 0.68245 & $0.00001^{*}$ & $0.01388^{*}$ & 0.15219 \\
\hline $\begin{array}{c}\text { Water } \\
\text { transparency }\end{array}$ & 0.44728 & 0.59335 & 0.88089 & 0.58371 & 0.87720 & 0.59336 \\
\hline $\mathrm{R}^{2}$ & 0.7497 & 0.5687 & 0.5859 & 0.8094 & 0.5656 & 0.5694 \\
\hline
\end{tabular}

*Significant results $(\mathrm{p}<0.05)$. 
of species in ecosystems (Pinel-Alloul et al., 1988; Pinel-Alloul, 1995). The water thermal and chemical stratifications in Sapucaí compartment might have influenced the distribution of some Cladocera species, making the community also stratified.

From the 14 species of Cladocera recorded, only Ceriodaphnia silvestrii and C. cornuta have shown a nocturnal migration pattern along the nictemeral cycle. According to the statistical analysis, the vertical distribution of these species was influenced by electrical conductivity, chlorophyll- $a$ and dissolved oxygen concentrations. The vertical distribution of zooplankton community in Lake Amapá (Acre state, Brazil) was analyzed by Keppeler \& Hardy (2004) who recorded higher densities of organisms in the middle of the water column, sought to be related to highest concentrations of algae. At night, $C$. silvestrii and $C$. cornuta might have migrated to the surface for feeding, as the highest chlorophyll- $a$ concentrations were recorded on the surface and middle of the water column.

Furthermore, many authors have reported that the migration of species to deeper layers, even under anoxic conditions, confers a metabolic advantage to them, given the exchange between feeding at higher and resting at lower temperatures (Hardy, 1936; Lampert, 1989; Hays, 2003). In the present study, these metabolic advantages might have been the reason for the positive relationship of $C$. silvestrii and $C$. cornuta species with the dissolved oxygen concentrations. At the bottom of the water column, the concentrations of dissolved oxygen were close to anoxia, which may have triggered the upward movement of these species. It is well known that oxygen concentrations influence the occurrence, composition, and abundance of aquatic aerobic organisms, since this element is crucial to several metabolic processes (Hutchinson, 1975; Aprile \& Darwich, 2009).

A similar migratory pattern was previously observed for Ceriodaphnia cornuta, which was found to be being mainly affected by water transparency (Nogueira \& Panarelli, 1997; Freitas et al., 2012). According to Lazzaro (1987), planktivorous fish can capture zooplankton through a suction mechanism, and cladocerans are the most vulnerable given their low escape capacity. Thus, as a strategy to escape, these organisms would inhabit the surface of the water column at night, where predation is supposed to be lower (Zaret \& Suffern, 1976; Dodson, 1990; Liu et al., 2003). Zaret \& Kerfoot (1975) found that the predation of Cladocera by fish was mainly stimulated by the visibility of pigmentation in their compound eyes under high luminosity, rather than by the body size. Therefore, the morphological characteristics and polymorphism within the same species may also influence the vertical distribution of their populations. In the case of the three forms of Ceriodaphnia cornuta, the 'cormorant' morpho-type (C. cornuta rigaudi) is more targeted by fish species (Zaret, 1972). Hence, the populations of C. cornuta with typical morphology (C. cornuta cornuta) has a reproductive advantage compared to other forms, increasing its population density. This can explain the higher densities of $C$. cornuta cornuta found here if compared to the other morphotypes.

The appearance of spines in Ceriodaphnia cornuta forms may be also related to the presence of predators. Rietzler et al. (2008) observed that the presence of Chaoborus sp. influenced the appearance of spines in this species. Both the presence of Chaoborus larvae and the high densities of C. cornuta cornuta may have influenced morphological changes in this species morphotype leading to high densities of organisms with spines. However, the larvae of Chaoborus sp. also presented a vertical migration. Many authors corroborate the theory that zooplankton may exhibit a normal migration pattern to escape from predation of Chaoborus sp. (Perticarrari et al., 2004; Bezerra-Neto et al., 2009). Yet, the food preference of Chaoborus sp. larvae depends on the instar in which they are, as well as the size of prey. They may prefer copepods and rotifers over cladocerans, as copepods and rotifers have a cylindrical form and small size, respectively, what facilitates the swallowing (Swift \& Fedorenko, 1975). Therefore, C. cornuta may not be the most targeted prey of Chaoborus sp. because of the spines. The same nocturnal migration pattern of prey and predator and the high densities of C. cornuta cornuta can be mainly explained by this cladoceran escape from planktivorous fish preying visually.

The species Bosmina cf. longirostris showed short movements throughout the daytime and migrated from surface to the middle of the water column, showing no clear migration pattern. No significant correlation was observed between the migration pattern of $B$. cf. longirostris with the physical variables if chemical of the water. The movements of species from this genus might be related to a metabolic optimization, as they are filter-feeder species (Ramos-Jiliberto et al., 2004; Previattelli et al., 2005). The species $B$. cf. longirostris (O. F. Müller, 1776) has a confused systematics, and many records of the genus need to be revised since it can be 
confused with $B$. freyii, both of which occurring in Brazil (Elmoor-Loureiro et al., 2004). Both species have already been recorded in the Furnas reservoir, B. freyii by Santos et al. (2010), and B. longirostris by Melo et al. (2017). Santos-Wisniewski et al. (2011) also identified both species, B. freyii and $B$. longirostris, in the same reservoir. However, in the present study, all individuals found were identified as Bosmina cf. longirostris.

During night time, $D$. birgei and $D$. spinulosum displayed only short movements which prevented the recognition of any migration pattern. However, many authors have already recorded a vertical migration pattern for these species (Nogueira \& Panarelli, 1997; Ramos-Jiliberto et al., 2004; Silva et al., 2011). Tomm et al. (1992) verified the same pattern for other cladoceran species, particularly Diaphanosoma birgei. No vertical migration was found for zooplankton species in Lake Calado, Amazonas basin, by Fisher et al. (1983). Some authors suggested that the quality and quantity of food may influence the vertical distribution of zooplankton along the water column. In this study, species of the genus Diaphanosoma remained on the surface, an area with highest concentrations of chlorophyll $a$, thus suggesting that such variable is possibly a limiting factor for this species as well.

Other factors such as trophic degree and presence of contaminants may also influence zooplankton migration patterns, especially among the cladocerans that are more stress responsive. Gutierrez et al. (2012) observed a reduction in the swimming capacity of some Cladocera species when exposed to sublethal concentrations of pesticides (chromium and endosulfate). The present study was carried out in a reservoir compartment with high trophic degree and pollutant inputs, which may have influenced the migratory behavior of the studied species. Melo et al. (2017) found abnormalities in some species of Cladocera in regions near the sampling sites of this study, such morphological alterations were linked to a continuous eutrophication process by which the reservoir was undergoing.

Therefore, in this study, we conclude that the thermal and chemical stratifications were important ecological factors influencing the migratory behavior of cladocerans. Only three species migrated, supporting the theory that the up ward movement of some species is affected by the barrier created by the water column stratification process. In addition, predation and food availability also appear to have influenced the vertical migration pattern.

\section{Acknowledgements}

We thank the Postgraduate Program of the Federal University of Alfenas - UNIFAL.

\section{References}

AMERICAN PUBLIC HEALTH ASSOCIATION APHA. American Water Works Association. Water Pollution Control Federation. Standard methods for the examination of water and wastewater. 22th ed. Washington: APHA, 2012, pp. 111-155.

APRILE, F.M. and DARWICH, A.J. Regime térmico e a dinâmica do oxigênio em um lago meromítico de águas pretas da região Amazônica. Brazilian Journal of Aquatic Science and Technology, 2009, 13(1), $37-$ 43. http://dx.doi.org/10.14210/bjast.v13n1.p37-43.

BARBOSA, F.A.R. and PADISÁK, J. The forgotten lake stratification pattern: atelomixis, and its ecological importance. Verhandlungen des Internationalen Verein Limnologie, 2002, 28, 1385-1395.

BAYLY, I.A.E. Aspects of diel vertical migration in zooplankton and its enigma variations. In: P. DEDECKKER and W.D. WILLIAMS, eds. Limnology in Australia. Australia: CSIRO, 1986, pp. 349-368. http://dx.doi.org/10.1007/978-94-009-4820-4_22.

BECKER, V., CARDOSO, L.S. and HUSZAR, V.L.M. Diel variation of phytoplankton functional groups in a subtropical reservoir in southern Brazil during an autumnal stratification period. Aquatic Ecology, 2009, 43(2), 285-293. http://dx.doi.org/10.1007/ s10452-008-9164-0.

BEZERRA-NETO, J.F. and PINTO-COELHO, R.M. Diel vertical migration of the copepod Thermocyclops inversus (Kiefer, 1936) in a tropical reservoir: the role of oxygen and the spatial overlap with Chaoborus. Aquatic Ecology, 2007, 41(535), 545.

BEZERRA-NETO, J.F., MELLO, N.A.S.T., MAIABARBOSA, P.M. and PINTO-COELHO, R.M. The role of predation in the diel vertical migration of zooplankton in two tropical freshwaters ecosystems. Acta Limnologica Brasiliensia, 2009, 21(1), 45-56.

CANTIN, A., BEISNER, B.E., GUNN, J.M., PRAIRIE, Y.T. and WINTER, J.G. Effects of thermocline deepening on lake plankton communities. Canadian Journal of Fisheries and Aquatic Sciences, 2011, 68(2), 260-276. http://dx.doi.org/10.1139/F10-138.

CODY, M.L. Introduction to long-term community ecological studies. In: M.L. CODY and J.A. SMALLWOOD, eds. Long-term studies of vertebrate communities. New York: Academic Press, 1996. http://dx.doi.org/10.1016/B978-0121780753/50002-7.

CUVIER, G. Le rèegne animal. Paris: Masson, 1817.

DAJÓZ, R. Ecologia geral. 4th ed. Petrópolis: Vozes, 1983, 472 p. 
DODSON, S. Predicting diel vertical migration of zooplankton. Limnology and Oceanography, 1990, 35(5), 1195-1200. http://dx.doi.org/10.4319/ lo.1990.35.5.1195.

DOMIS, L.N.S., ELSER, J.J., GSELL, A.S., HUSZAR, V.L.M., IBELINGS, B.W., JEPPESEN, E., KOSTEN, S., MOOIJ, W.M., ROLAND, F., SOMMER, U., DONK, E.V., WINDER, M. and LÜRLING, M. Plankton dynamics under different climatic conditions in space and time. Freshwater Biology, 2013, 58(3), 463-482. http://dx.doi. org/10.1111/fwb.12053.

ELMOOR-LOUREIRO, L.M.A. Manualde identificação de Cladóceros límnicos do Brasil. Brasilia: Universa, 1997.

ELMOOR-LOUREIRO, L.M.A., MENDONÇAGALVÂO, L. and PADOVESI-FONSECA, C. New cladoceran records from Lake Paranoá, Central Brazil. Brazilian Journal of Biology $=$ Revista Brasileira de Biologia, 2004, 64(3A), 415-422. http:// dx.doi.org/10.1590/S1519-69842004000300006. PMid:15622840.

FISHER, T.R., MELACK, J.M., ROBERTSON, B., HARDY, E.R. and ALVES, L.F. Vertical distribution of zooplankton and physico-chemical conditions during a 24-hour period in an Amazon floodplain lake - Lago Calado, Brazil. Acta Amazonica, 1983, 13(3-4), 475-487. http://dx.doi.org/10.1590/1809439219831334475.

FLIK, B.J.G. and RINGELBERG, J. Influence of food availability on the initiation of diel vertical migration (DVM) in Lake Maarsseveen. Archiv für Hydrobiologie-Beiheft Ergebnisse der Limnologie, 1993, 39, 57-65.

FREITAS, G.T.P., CRISPIM, M.C. and MELOJÚNIOR, H.N. Effects of net cages on the vertical distribution of zooplankton in a semi-arid reservoir, northeastern Brazil. Acta Limnologica Brasiliensia, 2012, 24(2), 140-148. http://dx.doi.org/10.1590/ S2179-975X2012005000033.

FURNAS CENTRAIS ELÉTRICAS S.A. - FURNAS [online]. Rio de Janeiro, 2015 [viewed 2 May 2015]. Available from: http://www.furnas.com.br

GOLTERMAN, H.L., CLYMO, R.S. and OHNSTAD, M.A.M. Methods for physical and chemical analysis of freshwaters. Oxford: Blackwell Scientific Publications, 1978.

GUTIERREZ, M.F., GAGNETEN, A.M. and PAGGI, J.C. Exposure to sublethal chromium and endosulfan alter the diel vertical migration (DVM) in freshwater zooplankton crustaceans. Ecotoxicology, 2012, 21(1), 37-47. http://dx.doi.org/10.1007/s10646-011-07617. PMid:21842398.

HARDY, A.C. Plankton ecology and the hypothesis of animal exclusion. Proceedings of the Linnean Society of London, 1936, 148(2), 64-70. http://dx.doi. org/10.1111/j.1095-8312.1936.tb00092.x.

HAYS, G.C. A review of the adaptive significance and ecosystem consequences of zooplankton diel vertical migrations. Hydrobiologia, 2003, 503(1-3), 163-170. http://dx.doi.org/10.1023/ B:HYDR.0000008476.23617.b0.

HUDEC, I. Subgeneric differentiation within Kurzia (Crustacea; Anomopoda; Chydoridae) and a new species from Central America. Hydrobiologia, 2000, 421(1), 165-178. http://dx.doi. org/10.1023/A:1003919712255.

HUTCHINSON, G.E. A treatise on limnology: introduction to lake biology and their limnoplankton. New York: John Wiley \& Sons, 1967. vol. 2.

HUTCHINSON, G.E. A treatise on limnology: geography, physics and chemistry. New York: John Wiley \& Sons, 1975. vol. 1.

KEPPELER, E.C. and HARDY, E.R. Vertical distribution of zooplankton in the water column of Lago Amapá, Rio Branco, Acre, Brazil. Revista Brasileira de Zoologia, 2004, 21(2), 169-177. http:// dx.doi.org/10.1590/S0101-81752004000200002.

KINGSOLVER, J.G. The well-temperatured biologist. American Naturalist, 2009, 174(6), 755-768. PMid:19857158.

KOTOV, A.A., ISHIDA, S. and TAYLOR, D.J. Revision of the genus Bosmina (Cladocera: Bosminidae), based on evidence from male morphological characters and molecular phylogenies Baird, 1845. Zoological Journal of the Linnean Society, 2009, 156(1), 1-51. http:// dx.doi.org/10.1111/j.1096-3642.2008.00475.x.

LAMPERT, W. The adaptive significance of diel vertical migration of zooplankton. Functional Ecology, 1989, 3(1), 21-27. http://dx.doi.org/10.2307/2389671.

LANDA, G.G., DEL-AGUILA, L.M.R. and PINTOCOELHO, R.M. Distribuição espacial e temporal de Kellicottia bostoniensis (Rousselet, 1908) (Rotifera) em um grande reservatório tropical (reservatório de Furnas), Estado de Minas Gerais, Brasil. Acta Scientiarum, 2002, 24(2), 313-319.

LAZZARO, X. A review of planktivorous fishes: their evolution, feeding, behaviours, selectivities, and impacts. Hydrobiologia, 1987, 146(2), 97-167. http:// dx.doi.org/10.1007/BF00008764.

LIU, S.-H., SUN, S. and HAN, B.P. Diel vertical migration of zooplankton following optimal food intake under predation. Journal of Plankton Research, 2003, 25(9), 1069-1077. http://dx.doi.org/10.1093/ plankt/25.9.1069.

MAIA-BARBOSA, P.M., ESKINAZI-SANT'ANNA, E.M. and BARBOSA, F.A.R. Zooplankton composition and vertical distribution in a tropical, monomictic lake (Dom Helvécio lake, southeastern Brazil). Acta Limnologica Brasiliensia, 2003, 15(1), 65-74. 
MATSUMURA-TUNDISI, T. Composition and vertical distribution of zooplankton in Lake Dom Helvécio. In: G.J. TUNDISI and Y. SAIJO, eds. Limnological studies on the Rio Doce Valley Lakes, Brazil. São Paulo: Brazilian Academy of Sciences, 1997.

MATSUMURA-TUNDISI, T., OKANO, W. and TUNDISI, J.G. Vertical migration of Copepoda populations in the tropical monomictic Lake Dom Helvécio. In: G.J. TUNDISI and Y. SAIJO, eds. Limnological studies on the Rio Doce Valley Lakes, Brazil. São Paulo: Brazilian Academy of Sciences, 1997.

MATSUMURA-TUNDISI, T., TUNDISI, J.G. and TAVARES, L.S. Diel migration and vertical distribution of Cladocera in Lak e D. Helvecio (Minas Gerais, Brazil). Hydrobiologia, 1984, 113(1), 299-306. http://dx.doi.org/10.1007/BF00026616.

MELO, R.R.R., COELHO, P.N., SANTOSWISNIEWSKI, M.J., WISNIEWSKI, C. and MAGALHÃES, C.S. Morphological abnormalities in cladocerans related to eutrophication of a tropical reservoir. Journal of Limnology, 2017, 76(1), 94-102.

MINTO, W.J., ARCIFA, M.S. and PERTICARRARI, A. Experiments on the influence of Chaoborus brasiliensis Theobald, 1901 (Diptera: Chaoboridae) on the diel vertical migration of microcrustaceans from Lake Monte Alegre, Brazil. Brazilian Journal of Biology = Revista Brasileira de Biologia, 2010, 70(1), 25-35. http://dx.doi.org/10.1590/S151969842010000100006. PMid:20231957.

MITAMURA, O. and HINO, K. Distribution of biogeochemical constituents in the waters. In: G.J. TUNDISI and Y. SAIJO, eds. Limnological studies on the Rio Doce Valley Lakes, Brazil. São Paulo: Brazilian Academy of Sciences, 1997.

NOGUEIRA, M.G. and PANARELLI, E. Estudo da migração vertical das populações zooplanctônicas na represa de Jurumirim (Rio Paranapanema - São Paulo, Brasil). Acta Limnologica Brasiliensia, 1997, 9, 55-81.

OHMAN, M.D., FROST, B.W. and COHEN, E.H. Reverse diel vertical migration: an escape from invertebrate predators. Science, 1983, 220(4604), 1404-1407. http://dx.doi.org/10.1126/ science.220.4604.1404. PMid:17730658.

PAGGI, J.C. Nota sistemática acerca de algunos cladóceros del género Chydorus, Leach, 1843, de la Republica Argentina. Physis, 1972, 31(82), 223-236.

PAYNE, A.L. The ecology of tropical lakes and rivers. New York: John Wiley \& Sons, 1986, 301 p.

PERTICARRARI, A., ARCIFA, M.S. and RODRIGUES, R.A. Diel vertical migration of copepods in a Brazilian lake: a mechanism for decreasing risk of Chaoborus predation? Brazilian Journal of Biology = Revista Brasileira de Biologia,
2004, 64(2), 289-298. http://dx.doi.org/10.1590/ S1519-69842004000200015. PMid:15462303.

PICAPEDRA, P.H.S., LANSAC-TÔHA, F.A. and BIALETZKI, A. Diel vertical migration and spatial overlap between fish larvae and zooplankton in two tropical lakes, Brazil. Brazilian Journal of Biology = Revista Brasileira de Biologia, 2015, 75(2), 352361. http://dx.doi.org/10.1590/1519-6984.13213. PMid:26132018.

PINEL-ALLOUL, B. Spatial heterogeneity as a multi scale characteristic of zooplankton community. Hydrobiologia, 1995, 300-301(1), 17-42. http:// dx.doi.org/10.1007/BF00024445.

PINEL-ALLOUL, B., DOWNING, J.A., PERUSSE, M. and CODIN-BLUMER, G. Spatial heterogeneity in freshwater zooplankton; variation with body size, depth and scale. Ecology, 1988, 69(5), 1393-1400. http://dx.doi.org/10.2307/1941636.

PREVIATTELLI, D., SANTOS-SILVA, E.N. and DARWICH, A.S. Distribuição vertical do zooplâncton e sua relaçáo com as variáveis ambientais. Distribuição vertical do zooplâncton e sua relação com as variáveis ambientais. In: E.N. SANTOSSILVA, F.M. APRILE, V.V. SCUDELLER and S. MELO, eds. Diversidade biológica e sociocultural do Baixo Rio Negro, Amazônia Central. Manaus: INPA, 2005.

RAMOS-JILIBERTO, R., CARVAJAL, J.L., CARTER, M. and ZUNIGA, L.R. Diel vertical migration patterns of three zooplankton populations in a Chilean lake. Revista Chilena de Historia Natural, 2004, 77(1), 29-41. http://dx.doi.org/10.4067/ S0716-078X2004000100004.

RIETZLER, A.C., ROCHA, O., ROCHE, K.F. and RIBEIRO, M.M. Laboratory demonstration of morphological alterations in Ceriodaphnia cornuta Sars (1885) fa rigaudi induced by Chaoborus brasiliensis Theobald (1901). Brazilian Journal of Biology = Revista Brasileira de Biologia, 2008, 68(2), 453-454. http://dx.doi.org/10.1590/S151969842008000200032. PMid:18660979.

SÁ-JUNIOR, W.P. Production of planktonic biomass for feed of alevins at the Furnas hydrobiology and hatchery station. In: R.M. PINTO-COELHO, A. GIANI and E.V. SPERLINGET, eds. Ecology and human impact on lakes and reservoirs in Minas Gerais with special reference to future development and management strategies. Belo Horizonte: Segrac, 1994.

SANTOS, R.M., NEGREIROS, N.F., SILVA, L.C., ROCHA, O. and SANTOS-WISNIEWSKI, M.J. Biomass and production of Cladocera in Furnas Reservoir, Minas Gerais, Brazil. Brazilian Journal of Biology = Revista Brasileira de Biologia, 2010, 70(3), 879-887, Supplement. http://dx.doi.org/10.1590/ S1519-69842010000400019. PMid:21085793.

SANTOS, R.M., SAGGIO, A.A., SILVA, T.L.R., NEGREIROS, N.F. and ROCHA, O. Short-term 
thermal stratification and partial overturning events in a warm polymictic reservoir: effects on distribution of phytoplankton community. Brazilian Journal of Biology = Revista Brasileira de Biologia, 2015, 75(1), 19-29. http://dx.doi.org/10.1590/15196984.05313. PMid:25945617.

SANTOS-WISNIEWSKI, M.J., MATSUMURATUNDISI, T., NEGREIROS, N.F., SILVA, L.C., SANTOS, R.M. and ROCHA, O. O estado atual do conhecimento da diversidade dos Cladocera (Crustacea, Branchiopoda) nas águas doces do Estado de Minas Gerais. Biota Neotropica, 2011, 11(3), 287-301. http://dx.doi.org/10.1590/S167606032011000300024 .

SARMENTO, H. New paradigms in tropical limnology: the importance of the microbial food web. Hydrobiologia, 2012, 686(1), 1-14. http://dx.doi. org/10.1007/s10750-012-1011-6.

SARTORI, L.P., NOGUEIRA, M.G., HENRY, R. and MORETTO, E.M. Zooplankton fluctuations in Jurumirim Reservoir (São Paulo, Brazil): a threeyear study. Brazilian Journal of Biology = Revista Brasileira de Biologia, 2009, 69(1), 1-18. http:// dx.doi.org/10.1590/S1519-69842009000100002. PMid:19347141.

SILVA, A.M.A., MEDEIROS, P.R., SILVA, M.V.B.C. and BARBOSA, J.E.L. Diel vertical migration and distribution of zooplankton in a tropical Brazilian reservoir. Biotemas, 2011, 22(1), 49-57. http://dx.doi. org/10.5007/2175-7925.2009v22n1p49.

SMIRNOV, N.N. Cladocera: the Chydorinae and Sayciinae (Chydoridae) of the world. Amsterdam: SPB Academic Publishing, 1996.

STATSOFT. Statistica for Windows (data analysis software system). Version 13.0. Tulsa: StatSoft, 2005.

SWIFT, M.C. and FEDORENKO, A.Y. Some aspects of prey capture by Chaoborus larvae. Limnology and Oceanography, 1975, 20(3), 418-425. http://dx.doi. org/10.4319/lo.1975.20.3.0418.

TALLING, J.F. The annual cycle of stratification and phytoplankton growth in Lake Victoria (East Africa). Internationale Revue der Gesamten Hydrobiologie, 1966, 51(4), 545-621. http://dx.doi.org/10.1002/ iroh. 19660510402.

TER-BRAAK, C.J.F. and ŠMILAUER, P. Canoco reference manual and CanoDraw for Windows user's guide: software for canonical community ordination. Ithaca: Microcomputer Power, 2002.

THACKERAY, S.J., GEORGE, D.G., JONES, R.I. and WINFIELD, I.J. Statistical quantification of the effect of thermal stratification on patterns of dispersion in a freshwater zooplankton community. Aquatic Ecology, 2006, 40(1), 23-32. http://dx.doi. org/10.1007/s10452-005-9021-3.
TOLEDO, A.P., TALARICO, M., CHINEZ, S.J. and AGUDO, E.G. A aplicação de modelos simplificados para a avaliação do processo da eutrofização em lagos e reservatórios tropicais. In: Anais do $12^{\circ}$ Congresso Brasileiro de Engenharia Sanitária e Ambiental. Río de Janeiro: ABES, 1983.

TOMM, I., POZZOBON, M.G.G., DALLA-COSTA, M.L.S.R. and LANSAC-TÔHA, F.A. Distribuição vertical nictemeral de crustáceos planctônicos em um braço do reservatório de Itaipu-PR. Revista Unimar, 1992, 14, 57-72.

TUNDISI, J.G. "Estratificação hidráulica” em reservatórios e suas consequências ecológicas. Ciência e Cultura, 1984, 36(9), 1489-1496.

VAN DAMME, K., SINEV, A.Y. and DUMONT, H.J. Separation of Anthalona gen.n. from Alona Baird, 1843 (Branchiopoda: Cladocera: Anomopoda): morphology and evolution of scraping stenothermic alonines. Zootaxa, 2011, 2875, 1-64.

WETZEL, R. Limnology: lake and river ecosystems. San Diego: Academic, 2001.

WISSEL, B. and RAMACHARAN, C.W. Plasticity of vertical distribution of crustacean zooplankton in lakes with varying levels of water colour. Journal of Plankton Research, 2003, 25(9), 1047-1057. http:// dx.doi.org/10.1093/plankt/25.9.1047.

XING, Z., FONG, D.A., YAT-MAN LO, E. and MONISMITH, S.G. Thermal structure and variability of a shallow tropical reservoir. Limnology and Oceanography, 2014, 59(1), 115-128. http:// dx.doi.org/10.4319/lo.2014.59.1.0115.

ZANATA, L.H. and ESPÍNDOLA, E.L.G. Longitudinal processes in Salto Grande Reservoir (Americana, SP, Brazil) and its influence in the formation of compartment system. Brazilian Journal of Biology = Revista Brasileira de Biologia, 2002, 62(2), 347-361. http://dx.doi.org/10.1590/S151969842002000200019 . PMid:12489407.

ZARET, T.M. and KERFOOT, W.C. Fish predation on Bosmina longirostris: Body size selection versus visibility selection. Ecology, 1975, 56(1), 232-237. http://dx.doi.org/10.2307/1935317.

ZARET, T.M. and SUFFERN, J.S. Vertical migration in zooplankton as a predator avoidance mechanism. Limnology and Oceanography, 1976, 21(6), 804-813. http://dx.doi.org/10.4319/lo.1976.21.6.0804.

ZARET, T.M. Predator-prey interaction in a tropical lacustrine ecosystem. Ecology, 1972, 53(2), 248-257. http://dx.doi.org/10.2307/1934078.

Received: 15 December 2017 Accepted: 03 October 2018 